\title{
THEORETICAL ASPECTS AND DEVELOPMENT OF THE MECHANISM FOR RISK MANAGEMENT IN SMALL- AND MEDIUM-SIZED BUSINESS
}

\author{
Aleksandra Lezgovko \\ Mykolas Romeris University, Insurance and risk management institute, Lithuania, aleksandra@draudimas.com
}

\begin{abstract}
Modern scientific research in the field of risk management is mainly devoted to general questions of the market theory of risk management, including qualitative risk analysis, protection of the rights of property owners and the study of the problems of selection of the best strategies for profitable market investments. The development of risk management mechanisms for small- and medium-sized businesses in Lithuania compared to other European markets is happening too slowly. The situation is aggravated by unstable situation of the field itself, corrupted officials and the lack of advanced control strategies for internal and external risk management in organisations. All these factors confirm the need to develop new management tools in the field of risk management at such enterprises. The aim of this article is to develop the mechanism of risk management of small and medium-sized businesses and justify it scientifically. The methodology of the research is based on the principles of objectivity using methods of comparative, logical, mathematical statistics and system-structural analysis.
\end{abstract}

Keywords: risk management; small and medium-sized businesses; the project process.

Type of the paper: Methodological paper

JEL Classification: D2, L2

\section{Introduction}

The scientific approach to the study of risk and risk-related issues has been taken by Lithuanian and foreign scientists for many years. We can distinguish such scholars as Bagdonas (1996), Kanapieckiene (2002), Cox (1994), Cooper (1987), Charette (1989), Lifson (1982), Ogenziht (1994), Raftery (2003), Rowe (2001), Schumpeter (2008) and others. At the same time, these researchers do not take into account the specifics of small- and medium-sized businesses and the sector as a whole.

It should be noted that the holistic and systematic mechanism of risk management of such enterprises, with consideration of the specifics of the industry and issues addressed, has been neither fully implemented nor researched. The analysis of the indicated sources confirms the need to study the best management methods and review the main guidelines and approaches to risk management in general. In connection with that, this article presents and classifies the risks specific to small- and mediumsized businesses and offers their own mechanism for managing these risks.

The aim of this article is to develop the mechanism of risk management of small- and medium-sized businesses and justify it scientifically.

In order to achieve this aim, the following tasks were accomplished:

- the need to develop the mechanism of risk management of small- and medium-sized businesses was proven;

- theoretical basis of risk management at these enterprises was studied;

- the mechanism for risk management based on project-integrated approach was developed;

- the specific nature of the optimisation of processes was identified and methodology to prevent problematic projects of risk management was developed.

The theoretical and methodological parts of the article are based on the works of western scholars, which are related to the theme of the present research, including materials and periodicals in the field of risk management and development of small- and medium-sized businesses. The methodology of the 
research is based on the principles of objectivity using methods of comparative, logical, mathematical statistics and system-structural analysis.

According to the author, today, there is an urgent need for a unified methodology of project management process of small and medium enterprises, as well as definitions of directions of optimisation and specificity of risk management portfolio.

\section{Risk classification}

The author, in the course of studying risks as well as relying on scientific research and the study of the main measures of state support of the industry, ranked and classified the risk inherent to small- and medium-sized businesses. It is proposed that all existing risks in small and medium enterprises should be classified according to the following levels: macro-level risks, meso-level risks and micro-level risks. Macro-level risks include risks such as country, inflation, competition, socio-demographic, legal and regulatory, force majeure and consumer risks. Meso-level risks include industry risks and risks associated with problems in the regions. Micro-level risks are the risks of specific risks of small- and medium-sized businesses that include all possible corporate risks, financial, investment and other economic risks. In Table 1, we'll look at the major types of these risks.

Table 1. Classification, causes, factors and methods of risk compensation in small- and medium-sized enterprises (Source: author's compilation)

\begin{tabular}{|c|c|c|c|}
\hline $\begin{array}{l}\text { Level of } \\
\text { risks }\end{array}$ & Risk type & Causes and risk factors & Compensation method \\
\hline \multirow{5}{*}{ 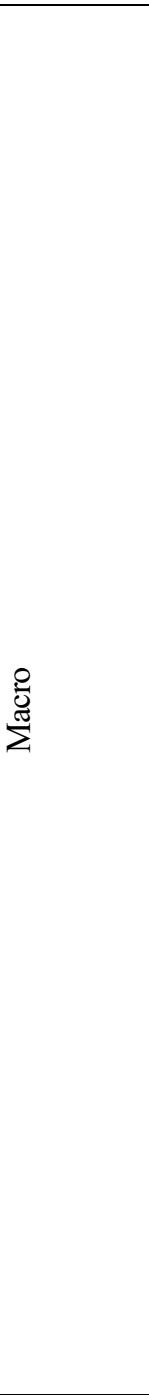 } & $\begin{array}{l}\text { Country risk } \\
\text { (economical- } \\
\text { political) }\end{array}$ & $\begin{array}{l}\text { The emergence of crisis, failures } \\
\text { of development strategies, } \\
\text { defaults, corruption, external } \\
\text { conflicts, unrest, political turmoil }\end{array}$ & $\begin{array}{l}\text { Consideration of trends of the current } \\
\text { and long-term development of the } \\
\text { country, statistical monitoring, planning } \\
\text { taking into account the development of } \\
\text { macroeconomic indicators, prediction of } \\
\text { interest rates, inflation, improve of the } \\
\text { reputation of the ruling power, } \\
\text { settlement of political and legal } \\
\text { conflicts, development of the foreign } \\
\text { economic indicators of the country }\end{array}$ \\
\hline & Inflation risk & $\begin{array}{l}\text { The crisis in the economy, low } \\
\text { purchasing power of the national } \\
\text { currency, a weak consumer } \\
\text { basket, unstable dynamics of } \\
\text { inflation }\end{array}$ & $\begin{array}{l}\text { Consideration of trends of development } \\
\text { of the country, stabilisation of the } \\
\text { national currency, use of the full list of } \\
\text { the instruments for the normalisation of } \\
\text { the exchange rate differences }\end{array}$ \\
\hline & Competitive risk & $\begin{array}{l}\text { Monopolization, unfavourable } \\
\text { competitive conditions in the } \\
\text { country, weak competitiveness in } \\
\text { the global arena and so on }\end{array}$ & $\begin{array}{l}\text { Creation of databases and systems about } \\
\text { market competitors, evaluation and } \\
\text { identification of market share, improving } \\
\text { competitiveness, stabilisation and } \\
\text { development of the commodity policy, } \\
\text { market segmentation, competitor } \\
\text { analysis }\end{array}$ \\
\hline & $\begin{array}{l}\text { Socio- } \\
\text { demographic } \\
\text { risk }\end{array}$ & $\begin{array}{l}\text { Dependence on buyers and } \\
\text { demographic situation, public } \\
\text { opinion, fertility and mortality } \\
\text { levels in the country }\end{array}$ & $\begin{array}{l}\text { Accounting and monitoring of effects } \\
\text { and changes in various socio- } \\
\text { demographic groups, adjusting the } \\
\text { strategy and tactics of the activities of } \\
\text { the organisations of the industry }\end{array}$ \\
\hline & $\begin{array}{l}\text { Force majeure } \\
\text { risk }\end{array}$ & $\begin{array}{l}\text { The impact of unforeseen } \\
\text { circumstances: social and other } \\
\text { natural environmental disasters, } \\
\text { crime and so on }\end{array}$ & $\begin{array}{l}\text { Accounting and establishing a system of } \\
\text { rapid response, development of models } \\
\text { of risk insurance and reinsurance }\end{array}$ \\
\hline
\end{tabular}




\begin{tabular}{|c|c|c|c|}
\hline & Consumer risk & $\begin{array}{l}\text { The presence or lack of } \\
\text { consumer demand, its dynamics, } \\
\text { level of stability }\end{array}$ & $\begin{array}{l}\text { Stabilisation of the market trends, } \\
\text { development of loyalty systems and the } \\
\text { creation of consumer databases }\end{array}$ \\
\hline & Price risk & $\begin{array}{l}\text { Level of dependence on prices of } \\
\text { raw materials, materials, fittings, } \\
\text { energy resources, labour and so } \\
\text { on }\end{array}$ & $\begin{array}{l}\text { Forecasting and accounting of industry } \\
\text { price dynamics, development of } \\
\text { strategies and mechanisms for the } \\
\text { regulation of prices }\end{array}$ \\
\hline \multirow{2}{*}{$\sum_{i}^{\infty}$} & Industry risk & $\begin{array}{l}\text { Problems of the developments of } \\
\text { the industry, its backwardness and } \\
\text { imbalance, weak capitalisation in } \\
\text { the industry as a whole, a lack of } \\
\text { effective strategies for industry } \\
\text { development }\end{array}$ & $\begin{array}{l}\text { The growth of industry capitalisation, } \\
\text { elimination of sectoral barriers and } \\
\text { imbalances, improving the competitiveness } \\
\text { of the industry in the country and the world }\end{array}$ \\
\hline & Regional risk & $\begin{array}{l}\text { Economic and political risks at the } \\
\text { regional level, social and other } \\
\text { factors of regional development }\end{array}$ & $\begin{array}{l}\text { The growth of the regional component in } \\
\text { the capitalisation of the companies in the } \\
\text { industry, maximisation of the value of the } \\
\text { industry assets in the region }\end{array}$ \\
\hline \multirow{4}{*}{ io } & Commodities risk & $\begin{array}{l}\text { The location of the company } \\
\text { considering the sources of raw } \\
\text { materials, dependence on suppliers } \\
\text { and the level of their impact on the } \\
\text { activity of the company }\end{array}$ & $\begin{array}{l}\text { The search of alternative sources of raw } \\
\text { materials, introduction of schemes of raw } \\
\text { materials, creation of stocks, mutual offset } \\
\text { transactions with suppliers of raw materials, } \\
\text { expansion of the number of suppliers, the } \\
\text { development of schemes of alternative } \\
\text { suppliers }\end{array}$ \\
\hline & $\begin{array}{l}\text { Scientific and } \\
\text { technical risk }\end{array}$ & $\begin{array}{l}\text { The lack of achievements of } \\
\text { scientific and technical progress in } \\
\text { the activity of the enterprise }\end{array}$ & $\begin{array}{l}\text { The search for new technologies, } \\
\text { improvement of the quality of products by } \\
\text { using new materials and means of } \\
\text { production, introduction of innovations }\end{array}$ \\
\hline & Investment risk & $\begin{array}{l}\text { Absence of external and internal } \\
\text { sources of financing, weak } \\
\text { capitalisation }\end{array}$ & $\begin{array}{l}\text { Prediction of investment activity, } \\
\text { maximising the market value, attracting } \\
\text { foreign investors, refinancing, participation } \\
\text { at international exhibitions, fairs and shows }\end{array}$ \\
\hline & $\begin{array}{l}\text { Risks of } \\
\text { corporate and } \\
\text { organisational } \\
\text { structure }\end{array}$ & $\begin{array}{l}\text { The lack of corporate governance } \\
\text { structure, lack of corporate culture, } \\
\text { inefficient organisational structure }\end{array}$ & $\begin{array}{l}\text { The improvement in the quality of } \\
\text { management, the effectiveness of the } \\
\text { form of construction of the company, } \\
\text { elements of the changes in the structure, } \\
\text { transition to vertical or horizontal } \\
\text { integration, changes in general } \\
\text { management and in management centres } \\
\text { according to responsibility as well as } \\
\text { changes in the document circulation and } \\
\text { information supply of divisions in the } \\
\text { company }\end{array}$ \\
\hline
\end{tabular}

The author also notes that the impact of these factors in developed and emerging markets is different. Thus, in developed markets, factors of micro level have bigger influence, whereas in emerging markets, factors of macro and meso levels have great significance. According to the author, in order to eliminate the existing risks as for today in the framework of a unified strategy for the development of small- and medium-sized businesses, the development of a universal mechanism for effective risk 
management is needed, which should take into account the specifics of management as well as the size of the company and all risk factors of the economy of the country as a whole.

\section{Introduction of Project Approach of Risk Management in Small- and Medium-Sized Businesses}

Having considered the theoretical foundations of risk management, the author proposes to consider risk management at small- and medium-sized businesses as the project process. It is a set of successive stages of risk management adopted by the company on the basis of existing strategic, tactical and operational plans. They should be aimed at the effective system-integrated management under the influence of the industry specifics, environment and competitiveness of the industry.

According to the author, in terms of implementation of the project approach, all risks of small- and medium-sized businesses should be considered comprehensively, taking into account their interrelationships. Thus, risk management should not focus only on one type of risks; on the contrary, it must consider all possible risks. Such approach is identified by the author as the system-integrated risk management.

The main advantage of this approach is systemic and holistic view of business risks. This provides with a better picture of risks faced by small- and medium-sized companies and, as a result, to get a more comprehensive approach to risk management in general. Otherwise, under the existing problems, there will be a fragmentation of activities and some risks will be given too much attention, whilst others will fall completely out of sight.

The author noted that this point of view provides with a better alignment with management decisions in other areas, especially with the strategic management, production management, personnel management and financial management. This is due to the fact that in some cases, it is difficult to draw a clear line between the divisions of the company management; so many risks (if not all) refer to issues of systemic management. If risk management is considered separately from other sections of management, there may be contradictions and conflict of interest in the system of management as a whole. In case of systematic approach and integrated solutions, such problems will not arise; therefore, risk management will be more efficient and control system more complex.

In addition, system-integrated risk management does not let to lose sight of the most important risks, which can be neglected by a manager in case of partial risk management.

Another advantage of the system-integrated risk management is that, thanks to the diversification of risks of different nature, the cost of activities for risk management of all types may be less than the appropriate measures estimated individually. Moreover, some activities, which were initially designed for other purposes (e.g. for quality control), may be used (sometimes with slight modifications) for risk management. This fact emphasises the complexity of the considered concept.

However, in the context of this article, the author highlights a number of limitations that can be encountered by small- and medium-sized business in the process of introducing the concept of integrated project risk management:

- the pursuit of the consideration of additional risks may become an end in itself when the meaning of risk management is lost as such;

- the relationships between the various risks are not obvious and require additional studies that would divert resources from the core business of the enterprise;

- a comprehensive analysis of a large number of risks requires a change in the information supply (in particular, the increasing need for statistical data suitable for quantitative analysis), which may not correspond the real possibilities;

- the integrated risk management, as a rule, requires a review of the whole decision-making system, which can cause a change in the organisational structure and affect the interests of the company's management;

- the complexity of the approach requires to improve the quality of decisions made, that is, it is associated with the demand of higher staff qualification (which means the possibility of refection of the new system and the need for retraining of personnel). 
Therefore, the introduction of risk management at the level of small and medium businesses takes a lot of effort. In general, the integrated risk management possesses all characteristics of an isolated system as it is defined in the general theory of systems. This demonstrates the possibility and necessity of research in this sphere of activity of managers as a separate area in all its diversity and logical unity.

Overall, the presented management mechanism includes the development of the project for risk management, direct management process, regulation of subsystems of project management, the formation of the portfolio of risk management projects as well as the process of assessing the effectiveness of the project of risk management.

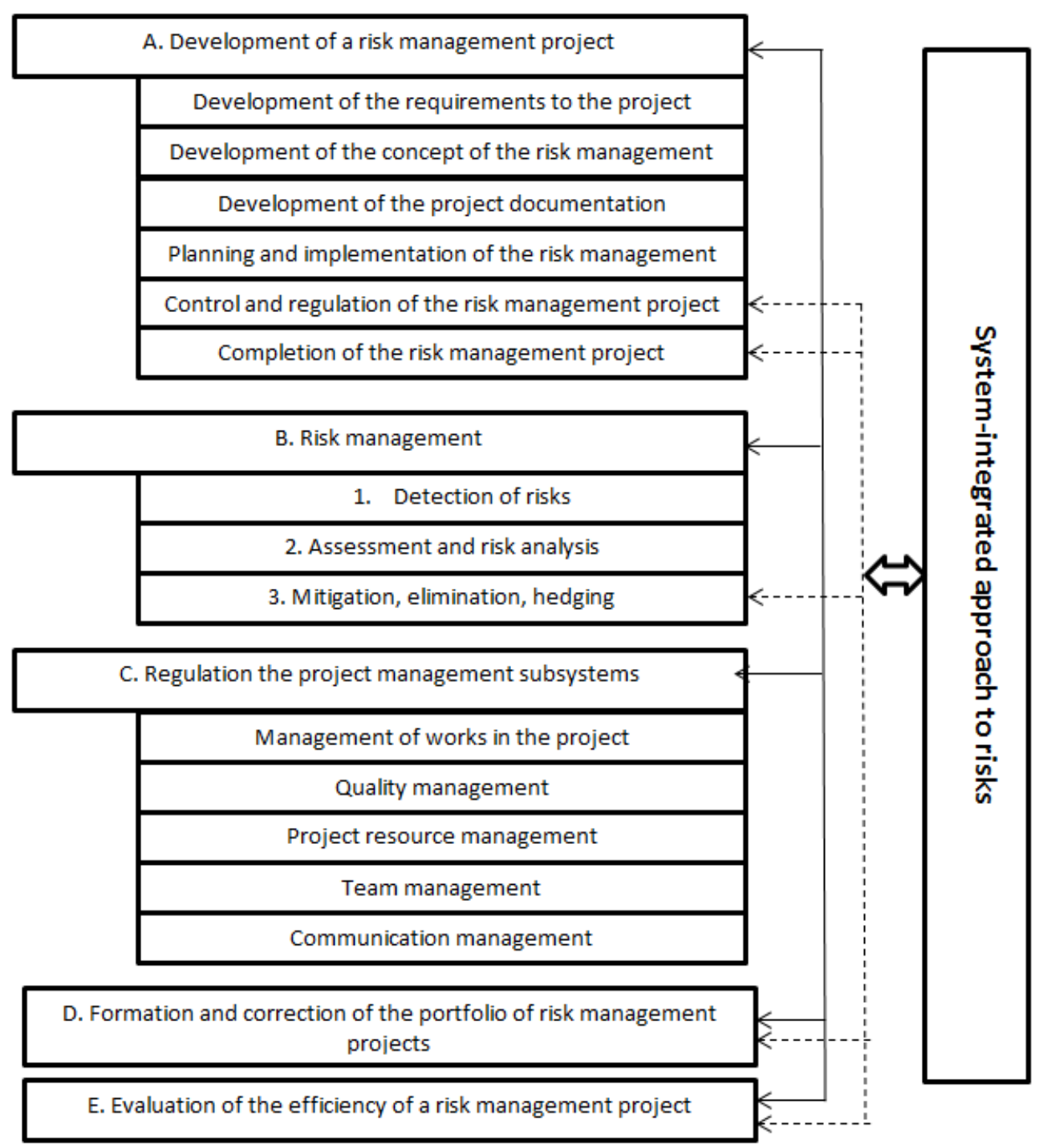

Fig. 1. The mechanism of risk management in small- and medium-sized businesses (Source: author's compilation)

The first module 'Development of the Risk Management Project' is of managerial nature; it is fundamental and is focused on the development of the project itself.

The development of the requirements for the risk management project should include the initial phase of the project and combines the initial project analysis, feasibility assessment and forecast of the effectiveness of the project, the choice of project financing as well as the organisation of the office of the project. 
The development of the concept for the risk management project should include important aspects such as the development of the strategy, goals and objectives of the project, expert evaluation of different project scenarios. It is at this stage the company management must form the systemintegrated management mechanisms and compile a description of sustainable management in the field of risk management.

The stage of development of project documentation is a very important moment in the creation of all risk management project. Particular importance in the development of project documentation should be given to cost estimation carried out at every stage of management as well as to the selection of computer-aided design system for organising the project documentation and project management in general.

With regard to the stage of project planning and implementation, the process of formation of decisions, which determines the sequence of certain events as well as actions and works on the project, must be included in the process of planning. Planning should take an important place in the management of the project because planning itself is the organisational start of the entire process for its implementation. In the context of the scientific article and under the conditions of application of the system-integrated approach to risk management, the author proposes to use calendar-network project planning.

The second module 'Risk Management' has a close relationship with the fourth module 'Formation and Updating of the Project Portfolio' and includes the detection process, evaluation, analysis as well as the stage of mitigation, elimination and hedging of risks. According to the author, effective risk management requires development of common methodology for risk management as the project process as well as identification of areas of optimisation and specific features of the portfolio of risk management projects.

The methodology of risk management as a project process, which is proposed by the author, contains a number of fundamental and original solutions. Its main advantage is an attempt to present the documented systemic approach to the problem of improving and enhancing the efficiency of the project process of uncertainties and risks by creating a constructive framework for implementation of effective projects to minimise risks of small- and medium-sized businesses.

The initial stage in creating an effective project process is based on the development of optimal project policy aimed at the production of an integrated approach and implementation of the quality management system as a controlling system.

The author particularly notes that today, in many small- and medium-sized businesses, the project policy, if there is, serves only to satisfy the requirements of supervising bodies and owners, but not in order to express understanding of the situation and prospects of the development by the council and management. In this case, the project policy is a useless paper rather than a reflection of the reality of the market place of the enterprise in the market and integration of the risk management system. Such policy does not work and is ignored by executors.

The policy should be based on the reality. The document on the project policy should cover reasonable, generally accepted principles of project administration. The differences of documents on the project policy are based on the specifics of certain enterprises, their goals, peculiarities of the markets, their financial structures, size, intensity of the competitive situation, the experience of staff and direct impact of various risks on the activity of the company. Consequently, each company must develop its own individual policy, reflecting its specific needs and objectives in the field of risk management.

After the approval of the project policy and the development of standards and regulations, the management of the company needs to move to design, implementation and monitoring of risk management projects themselves.

The author also noted that in the course of their functioning, small- and medium-sized companies face not a single and uniform risk, but a diverse array of risks, which were classified previously. This means that risk management should be a single system of effective measures to overcome negative 
consequences of the impact of each risk element of this aggregate, that is, to manage the entire portfolio of risks comprehensively. Although certain elements of such integrated management occur at the early stages of development of risk management, they receive their completion in the concept of the integrated risk management, which was presented in the context of risk management mechanism.

The need for the management of the risk portfolio leads to the fact that it is examined in two stages:

- First, the analysis of each risk individually is performed. This empowers the risk manager to find out the specifics of a particular risk situation or the peculiarities of adverse effects because of the implementation of the estimated risk situation. This analysis empowers such a specialist to choose the most appropriate tools for managing each specific risk separately;

- Then, the entire risk portfolio is studied. This makes it possible to determine the overall impact of all risks in respect to this company. Such a comprehensive understanding about the totality of information on areas of possible risks as well as the guidance on carrying out preventive measures to minimise or prevent their implementation is called the risk profile and its documentary evidence - the risk passport. The performance of the above-mentioned activity creates a single point of view on the risks of the enterprise as a whole, what determines the characteristics of its risk management policy.

According to the author, the risk management system in small- and medium-sized companies should be based on these two stages and combine the tools and techniques specific to each of them. Failure to do so will result in the loss of adequacy of the implemented policy and, as a result, in a decrease in the company's financial stability.

The main problem of the creation of an integrated risk management system is the need to consider a large number of risks of a different nature with ill-structured and not always well-understood relationships as a whole. In other words, there is a question of risk mapping. All this requires to bring all risks to the 'common denominator', that is, to use such an indicator that would take into account the consequences of risks of any nature. Such operation is called risk aggregation. As any process of aggregation and generalisation, it leads to a loss of information, ignorance of the specifics of risk implementation and lower understanding of the notion of risk situation. But in return, it provides with a unified view of all the risks, to compare them and to allocate resources for the organisation of activities of risk management more effectively.

Obviously, the index, which could let to conduct risk aggregation, should be quite general, reflecting the results of the company activity as a whole. At the same time, this index should be free from subjectivism and formalism, which is often present in financial statements. Different approaches to risk measurement are possible, but it is necessary to choose an index that is consistent with the objectives of integrated risk management.

In practice, one of the options of residual profit, which is the difference between the net income and the cost of the capital, is selected to be used as such index. The most popular index of this type is economic value added (EVA), which has its own characteristics. The basic calculation scheme of this index is as follows. The base value is determined by the difference between the net operating profit after tax and costs of using the capital. The latter is calculated for the total capital (equity and liabilities) as the product of weighed average cost of capital (WACC) and its value. Wherein the corresponding multipliers can take into account not only actual values but also target rates. Further amendments are made to the base value, which are necessary to estimate its value in accordance with the economic content.

Let us designate the proportion of each component as $w(i)$, the required rate of return as $r(i)$, then the cost of the capital is the weighted average cost of individual components (formula 1):

$$
\mathrm{WACC}=\sum_{\mathrm{i}=1}^{\mathrm{N}} \mathrm{w}(\mathrm{i}) * \mathrm{r}(\mathrm{i})
$$


As in this case the value of pre-tax profit is used for the determination of the cost, it is necessary to take into account the fact that because of the interest on loan obligations, the taxable profit is reduced. Therefore, when substituting the value of liabilities in the formula above, this cost must be multiplied by the value $(1-T)$. As it is known, the purpose of the activity of the company is usually its capitalisation. Accordingly, the higher the cost of the capital of the company at a given value of income, the lower is its cost, and vice versa. Therefore, the task of maximising the value of the company is adequate to the problem of reducing the cost of capital. In this regard, in order to select the optimal capital structure, it is necessary to choose such vector of capital structure W that WACC (W) $\rightarrow \min$.

The objective would be commonplace if the value of various sources of funding were not dependent on capital structure. The higher the proportion of credit obligations, the higher, for example, is the level of risk for the company's shareholders. Therefore, the required rate of return by various types of financing depends on the share of the total capital structure, namely, $r(i)=F(W)$. This makes the task to be a very remarkable process.

In order to assess risks, the changes in the EVA are considered: the risk is considered to be higher, the more EVA decreases, caused by the risk itself. At the same time, the EVA is estimated not for the previous period, but its forecast for the future is carried out. Thus, this index allows profit, capital needs and risks to be related.

The change of the EVA is an example of a risk measure, that is, the index characterising the magnitude of risk. This indicator collects all information about the risk to a single number. Therefore, risk measures are a popular tool used in risk management. They may be general (universal), as the considered index, and partial, reflecting individual properties of the risk.

The author also emphasised that the stage of the process of risk management as a project as per today requires the creation of techniques based on the detection and prevention of the consequences of the emergence of problematic projects in the portfolio for the management of certain risks at the enterprise. Thus, the author developed stages (zones) of the deteriorating situation of the company until the moment the risk management projects becomes unprofitable and provided with recommendations for each stage of project deterioration.

The process is visualised and presented in Fig. 2. Point A, the appearance of the first symptoms of the problem; point $\mathrm{B}$, the detection of deterioration of symptoms; point $\mathrm{C}$, the beginning of a successful solution to the problem; Line $\mathrm{D}$, the successful elimination of the risk that an entity retains the bulk of the property and the project risk management; Line E, belated elimination: debts repaid, but the company loses a major part of the property and the project risk management is ineffective.

The considered stages indicate that the manager must carry out continuous training of their employees in the field of recognition of problematic projects. And the project management should see the problem and report back on it whilst the project is still in zone 1 or, in extreme cases, in zone 2 . The closer to the area of loss, the bigger number of valuable chances in the area of management a certain risk is lost by the company; therefore, in order to minimise the project losses and keep, if possible, assets of the company, it is crucial to see the problem in time and to act quickly to resolve it, by conducting strict control.

The third module of the risk management mechanism 'Regulation of subsystems of the project' is aimed at regulating sub-systems, such as basic operation, quality management, resource and communication management. 
Project quality

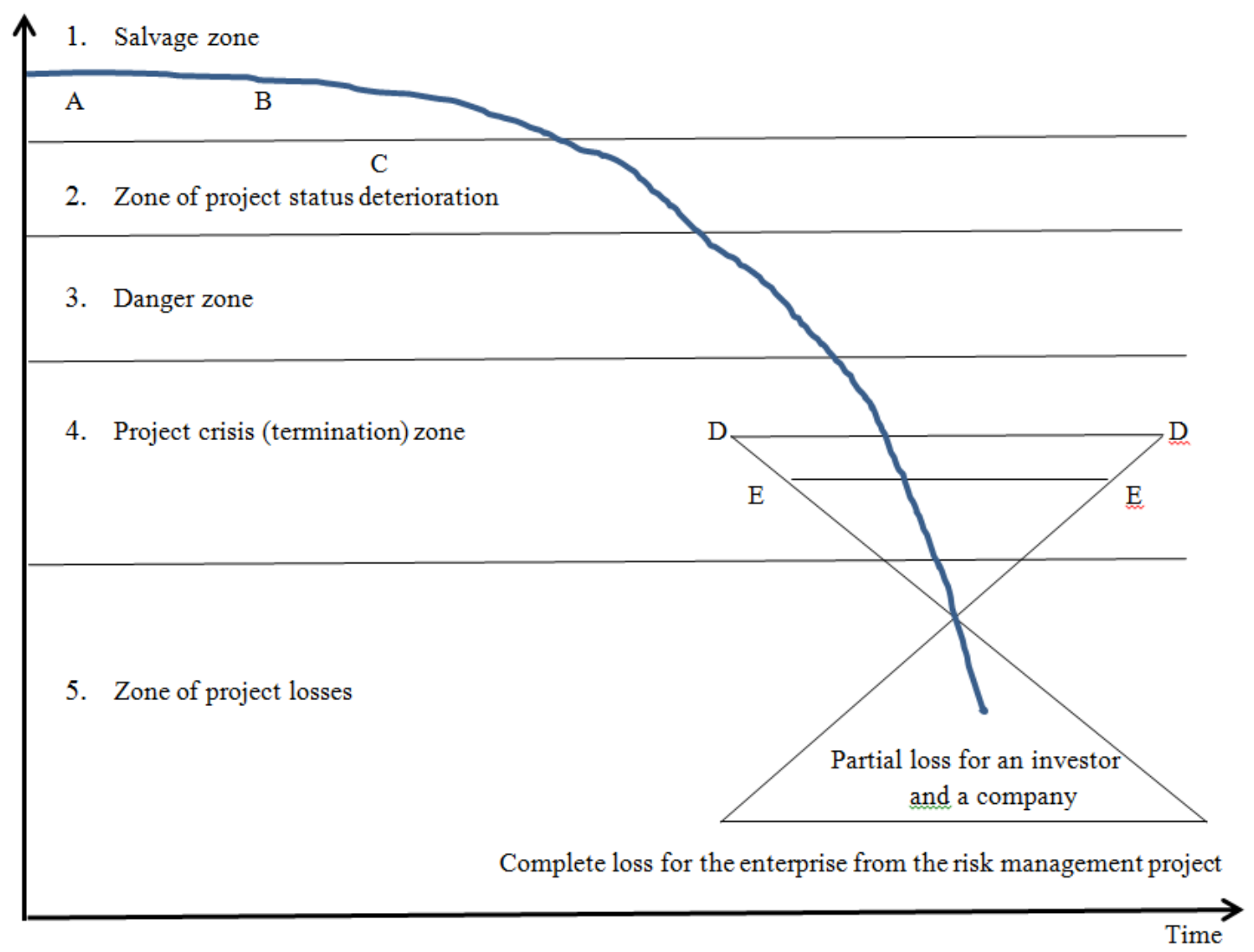

Fig. 2. Stages of quality deterioration of the risk management project of a company

(Source: author's compilation)

According to the author, in order to improve the effectiveness of risk management as a project at small- and medium-sized businesses, it is necessary to divide the entire process as a whole into individual interconnected complexes and work packets on assessment, minimisation and risk management. These activities should be clearly linked to timing and duration as well as resourcing and limitations. In this case, all the same network schedule can serve as a useful tool.

With regard to the project resource management in the context of risk minimisation at small- and medium-sized businesses, introduction of the internal control system for identification and use of efficiency reserves of various enterprise resources is recommended in this area.

\section{Conclusions}

In general, the author comes to the conclusion that at the present stage of research, it is already possible to say with certainty that the project process is a complex phenomenon that requires consideration of its essence at different levels. First of all, at the level of essential sensations, the risk management process is a specific tactical regulation on the implementation of measures for evaluation, forecast and risk management, which is based on subjective organisational norms. Second, at the socio-historical level, the project process is an evolutionary phenomenon that changes its content depending on the conditions of development and real needs of small- and medium-sized businesses in the risk management process. According to the author, the project process must have certain mechanisms that will create the right direction in the work of the enterprise and its risk management in particular. 


\section{References}

Bagdonas, V. (1996). Verslo rizika. Vilnius: Saulès vejas.

Balabanov, I. (1996). Risk Management. Moscow: Finance and Statistics.

Cox, T. (1994). Cultural diversity in organizations: theory, research and practice. Berrett Koehler Publishers.

Cooper, D. F., \& Chapman, C. B. (1987). Risk analysis for large projects: models, methods, and cases. John Wiley \& Sons Inc.

Charette, R. N. (1989). Software engineering risk analysis and management. New York: Intertext Publications.

Kanapickienè, R. (2002) Kontrolès procedūrų sistemos diegimas įmonèje . Vilnius: Inžinerinė ekonomika, Nr. 5 (31), p. 57-62.

Kleiner, G. (1994) Risks of industrial enterprises. Moscow: Russian Economic Journal (4).

Lezgovko, A. (2012). The classification causes factors and methods of risk compensation mechanism in the light industry. Moscow: State University of management bulletin (6), 48-53.

Liberson, V. (2002). Risk management in projects. In The conference "Project Management Company", Moscow: Vedomosti. Conference proceedings, 19-22

Lifson, M. W., \& Shaifer, E. F. (1982). Decision and Risk Analysis for Construction Management. John Wiley \& Sons Inc, 605 Third ave., New York, NY 10158.

Ogenziht, V. (1994). The problem of risk of industrial enterprises. Moscow: Progress, 238.

Marcelino-Sádaba, S., Pérez-Ezcurdia, A., Lazcano, A. M. E., \& Villanueva, P. (2014). Project risk management methodology for small firms. International Journal of Project Management, 32(2), 327-340.

McCartney, MP\&Flynn, T. (2005) Risk: the risk management at the level of top management and boards of directors. Moscow: Alpina Business Buck.

Raftery, J. (2003). Risk analysis in project management. Routledge.

Raizberg, B. (1992). Entrepreneurship and risk. Moscow: Infra-M.

Rowe, G., \& Wright, G. (2001). Differences in expert and lay judgments of risk: myth or reality?. Risk Analysis, 21(2), 341-356.

Schumpeter, J. (2008). Business cycles. Moscow: EKSMO.

Tepman, L. (2002). The risks in the economy. Moscow: Unity-Dana.

Walker, P., Grey, S., Raymond, G., \& Cooper, D. F. (2013). Project Risk Management Guidelines: Managing Risk in Large Projects and Complex Procurements. Wiley.

Ward, S. \& Chapman, C. (1995) Risk-management perspective on the project lifecycle. International Journal of Project Management, 13 (3), p. 145-149. 